\title{
PENDALAMAN ILMU AGAMA DAN PENGEMBANGAN KETERAMPILAN DI PP. ATH-THOHARIYYAH - PANDEGLANG
}

\section{IN-DEPTH THEOLOGY AND SKILL DEVELOPMENT IN PP. ATH-THOHARIYYAH - PANDEGLANG}

\author{
Nunu Ahmad An-Nahidl \\ Puslitbang Pendidikan Agama dan Keagamaan, Badan Litbang dan Diklat, Kementerian Agama \\ Jl. M.H. Thamrin No. 6 Jakarta Pusat, Daerah Khusus Ibukota Jakarta \\ email: intersym2013@gmail.com
}

Naskah Diterima: 19 September 2018; Direvisi: 15 November 2018; Disetujui: 02 Desember 2018

\begin{abstract}
This research aimed to study Islamic theology (tafaqquh fiddin) and skill development in PP. (Islamic Boarding School) Ath-Thohariyyah, Pandeglang. There are three aspects studied relating with the in-depth theology, i.e.: input aspect, process aspect, and output aspect. Meanwhile, three more aspects studied relating with skill development, i.e.: skill type, partnership, and benefit value. This qualitative research was conducted by using four techniques of data collection, i.e.: in-depth interview, participant observation, documentation studies, and triangulation. The research concluded that the main pilar of pesantren education in enhancing theology to build and lead the potential candidates of scholars (ulama) can be combined by developing skills in various types and choices, based on the ability and necessity of local regions, as well as the potential resources of each pesantren. PP. Ath-Thohariyyah can be the role model of pesantren that is inspiring and encouraging the creativity of other pesantrens in Pandeglang Regency, Banten, not only in providing various education services for students, but also in providing spiritual and mental development services, religious knowledge, and skill practices.
\end{abstract}

Keywords: In-depth Theology; Pesantren; Skill development

\begin{abstract}
Abstrak
Penelitian ini ingin mendeskripsikan pendalaman ilmu agama (tafaqquh fiddin) dan pengembangan keterampilan (life skills) di PP. Ath-Thohariyyah - Pandeglang. Ada tiga aspek yang dikaji terkait pendalaman ilmu agama, yaitu; aspek input, proses dan output. Sementara tiga aspek lain yang dikaji terkait pengembangan keterampilan adalah jenis keterampilan, kemitraan, dan nilai manfaat. Penelitian kualitatif ini dilakukan dengan empat teknik pengumpulan data, yaitu: wawancara mendalam, observasi partisipasi, studi dokumentasi, dan triangulasi. Penelitian ini menyimpulkan bahwa pokok utama pendidikan pesantren dalam hal pendalaman ilmu agama untuk mencetak dan mengkader calon ulama dapat dipadukan dengan mengembangkan keterampilan dalam berbagai jenis dan pilihan sesuai dengan kemampuan dan kebutuhan wilayah lokal setempat, serta potensi sumberdaya setiap pesantren. PP. Ath-Thohariyyah dapat menjadi model percontohan pesantren yang bisa menginspirasi dan mendorong kreativitas pesantren lain di wilayah Kabupaten Pandeglang Banten dalam upaya memberikan ragam layanan pendidikan kepada santri, selain kebutuhan mental spiritual dan pengetahuan keagamaan, juga kebutuhan praksis keterampilan.
\end{abstract}

Kata kunci: Pendalaman ilmu agama; Pesantren; Pengembangan keterampilan 


\section{PENDAHULUAN}

Pesantren tumbuh berkembang dari bawah dan didirikan atas hasil kerja keras masyarakat. Maka sejak awal keberadaannya, pesantren senantiasa identik dengan sejarah kemandirian. Lembaga pendidikan keagamaan ini memiliki mekanisme internal yang sangat otonom di dalam mengelola dan menyelenggarakan kegiatan pendidikan. Kiai adalah pengasuh dan sekaligus figur utama kemandirian pesantren. Kemandirian itu tidak saja ditemukan di dalam pandangan keagamaannya, melainkan juga di dalam tata cara mengapresiasi tawaran-tawaran pembaruan pesantren, baik sistem maupun kelembagaan yang acapkali menggugat kemandirian itu. Dalam perjalanannya, pesantren memang seringkali dihadapkan kepada sejumlah dinamika dan tantangan yang mengharuskannya membuka ruang bagi lebih banyak kebutuhan pengguna lembaga pendidikan itu, ketimbang tugas dan fungsinya selama ini.

Sebagai instrumen pengembangan ajaran Islam, akar kesejarahan pesantren adalah lembaga pencetak dan pengkaderan ulama. Sejarah mencatat keberhasilan pesantren memerankan tugas dan fungsinya sebagai lembaga pencetak ulama dengan lahirnya sebagian besar ulama tanah air dari rahim lembaga pendidikan itu. Hingga saat ini pun, para ulama tamatan pendidikan pesantren menjadi mata rantai yang tidak terputus dalam proses alih ilmu pengetahuan agama di berbagai lini kehidupan, baik melalui pembelajaran tatap muka di berbagai jalur, jenjang dan jenis pendidikan, maupun melalui karya tulis sebagian kecil dari para ulama itu. Di pesantren, pendidikan bukan sekedar kegiatan alih pengetahuan dan keahlian, tetapi juga kegiatan alih nilai dan budaya dalam suatu proses yang terus berkembang.

Dinamika pengembangan pendidikan pesantren kian hari kian menunjukkan kematangannya dalam bersinergi dengan berbagai kebutuhan dan kepentingan masyarakat. Isu modernisasi dan berbagai ide pembaruan pendidikan diapresiasi dan diinternalisasi dengan tanpa meninggalkan watak aslinya. Pesantren memiliki parameter yang cukup terukur dalam mengemas langkah penting yang perlu dilakukan dalam mengelola pengembangan pendidikan ke depan. Dalam tradisi pesantren, dikenal kaidah; "almuhafazhat ala al-qadim ash-shalih wa alakhdz bi al-jadid al-ashlah." Maknanya, pesantren konsisten menjaga keberlangsungan nilai dan tradisi yang baik dengan tidak menafikan perkembangan mutakhir yang logis, realistis dan relevan. Karena alasan itu pula, pesantren mampu kokoh secara meyakinkan hingga saat ini. Dalam istilah Gus Dur, gambaran kongkrit pengertian subkultur yang terdapat dalam kehidupan pesantren, minimal harus memiliki keunikannya sendiri dalam aspek-aspek berikut; cara hidup yang dianut, pandangan hidup dan tata nilai yang diikuti, serta hirarki kekuasaan intern tersendiri yang ditaaati sepenuhnya. ${ }^{1}$

Menurut Azra, respon pesantren terhadap modernisasi pendidikan Islam dan perubahan sosial ekonomi yang berlangsung dalam masyarakat Indonesia sejak awal abad ini mencakup; pertama, pembaruan substansi atau isi pendidikan pesantren dengan memasukkan subyek umum dan kejuruan; kedua, pembaruan metodologi, seperti sistem klasikal, penjenjangan; ketiga, pembaruan kelembagaan, seperti kepemimpinan pesantren, ragam lembaga pendidikan; dan keempat, pembaruan fungsi, dari semula hanya fungsi kependidikan, dikembangkan sehingga juga mencakup fungsi sosial-ekonomi. ${ }^{2} \quad$ Tegasnya, investasi pendidikan untuk masa depan memiliki banyak fungsi selain fungsi kependidikan itu sendiri, yaitu: fungsi ekonomis, politis, sosio-kultural dan fungsi kemanusiaan.

Faktanya, sebagian besar pesantren menerima semangat pembaruan dengan mengembangkan sistem pendidikan madrasah bahkan sekolah. Pada model pertama ini, dominasi penguatan pendidikan umum seringkali justru mereposisi fungsi pesantren menjadi lebih semacam asrama. Model kedua, direpresentasikan oleh pesantren yang mengambil sikap menolak sama sekali dan

\footnotetext{
${ }^{1}$ Abdurrahman Wahid. (1974). Pesantren sebagai Subkultur, dalam M. Dawam Raharjo (Ed). Pesantren dan Pembaruan. Jakarta: LP3ES, h. 43.

${ }^{2}$ Azyumardi Azra. Pesantren: Kontinuitas dan Perubahan, dalam Nurcholish Madjid. Bilik-bilik Pesantren. Jakarta: Penerbit Dian Rakyat, h. Xxiv.
} 
bertahan dengan pola yang telah lama berjalan. Pesantren ini tetap mempertahankan tradisi pengembangan intelektual pada sistem pendidikannya dengan berbasis kitab kuning. Sedangkan, model ketiga adalah pesantren yang mengambil jalan tengah, yaitu tetap mempertahankan pola lama dan turut mengapresiasi ide-pandangan yang lebih baru. Dalam hal ini, pemaknaan al-jadid al-ashlah tidak berarti bahwa pandangan baru itu lebih baik dari yang lama, namun lebih tepatnya, ia relevan dengan kebutuhan saat ini, dimana kehidupan manusia terus berubah mengikuti perkembangan kemajuan jaman.

Dalam konteks penelitian ini, pesantren yang memadukan pendalaman kajian agama dan pada saat yang sama juga mengembangkan pendidikan keterampilan dan kecerdasan tertentu, sesungguhnya ia sedang melakukan upaya penyelarasan nilai dan pandangan yang dianut. Di satu sisi, keteguhan pesantren sebagai pusat pengembangan tradisi intelektual ilmu-ilmu ke-Islaman, jelas penting dan strategis untuk menjawab kebutuhan masyarakat luas terhadap lahirnya kader ulama yang mumpuni. Era informasi dan globalisasi saat ini, dengan pengaruhnya yang luar biasa terhadap perilaku kehidupan masyarakat, jelas meniscayakan peran serta para ulama dalam menjawab dinamika sosial yang mengemuka. Menurut Mukti Ali, calon ulama masa depan dirasakan sulit -untuk tidak mengatakan tidak mungkin- dilahirkan dari sebuah sistem pendidikan di luar lembaga pesantren. ${ }^{3}$

Di sisi lain, pesantren juga perlu memperluas dan meningkatkan kualitas dan ragam layanan pendidikan bagi kebutuhan lebih banyak orang. Artinya, secara perlahan namun pasti, pesantren memasuki apa yang disebut dengan "pasar pendidikan." Dalam hal ini, pesantren sebagai sebuah komoditas dapat dikemas sedemikian rupa agar dapat lebih menarik minat pembeli dan konsumen. Persaingan dalam pasar pendidikan dapat menghasilkan kualitas lebih baik dan keuntungan lebih besar bagi para konsumen yang memilih lembaga pendidikan Islam

${ }^{3}$ Imam Suprayogo. (2012). Spirit Islam Menuju Perubahan dan Kemajuan. Malang: UIN Maliki Press, h. 256. terbaik yang saling bersaing. ${ }^{4}$ Dengan demikian, pendidikan pesantren semakin mampu bersaing, baik dari segi sistem maupun kelembagaan. Bahkan penyelarasan itu tidak semata-mata dalam rangka membangun kapasitas kelembagaan pesantren saja, melainkan juga dalam kepentingan lebih luas, yaitu membangun peradaban Islam itu sendiri.

Menurut Tholhah, dalam rangka menyiapkan sumberdaya manusia yang memiliki kemampuan, kepakaran serta berkarakter Islami, maka peradaban Islam saat ini membutuhkan sistem pendidikan yang memadukan ilmu pengetahuan, keterampilan dan moral. ${ }^{5}$ Dalam bahasa yang lebih praksis, ditegaskan Dhofier bahwa persoalan Islam di Indonesia sekarang ini, bukan semata-mata kualitas dan aktivitas pemikiran Islam tradisi pesantren, tetapi lebih disebabkan kepentingan pendidikan, ekonomi dan politik bangsa Indonesia. Sebagai negara kepulauan, maka aspek paling utama bagi seluruh bangsa Indonesia adalah kepentingan ekonomi yang pernah dihancurkan oleh Portugis dan Belanda pada masa kolonial. Bahkan pembedaan ragam kelompok umat Islam di Indonesia, bukan karena modern dan kolot, melainkan karena terbagi di dalam kehidupan sosial dan ekonomi yang beda. Satu kelompok tinggal di perkotaan dengan tingkat ekonomi dan pendidikan yang maju, sedangkan kelompok lainnya tetap tertinggal di desa, berpendidikan rendah dan dengan penghasilan yang rendah pula. ${ }^{6}$

Sebagai lembaga pendidikan yang umumnya berada di wilayah perdesaan, pesantren pun memiliki kontribusi cukup signifikan dalam proses perubahan sosial masyarakat. Bahkan beberapa pesantren di antaranya telah memiliki rekam jejak yang meyakinkan dalam upaya-upaya

${ }^{4}$ Virginia Hooker. (2009). Pemahaman Baru Wajah Pendidikan Islam di Indonesia. Prolog dalam Asrori S Karni. Etos Studi Kaum Santri: Wajah Baru Pendidikan Islam. Bandung: Penerbit Mizan, h. xxvi.

${ }^{5}$ Muhammad Tholhah Hasan. (2009). Mutu Pendidikan Islam sebagai Kunci Jawaban. Epilog dalam Asrori S Karni. Etos Studi Kaum Santri: Wajah Baru Pendidikan Islam. Bandung: Penerbit Mizan, h. 405.

${ }^{6}$ Zamakhsyari Dhofier. (2015). Tradisi Pesantren: Studi Pandangan Hidup Kiai dan Visinya Mengenai Masa Depan Indonesia. Jakarta: LP3ES, h. 14. 
pengembangan komunitas. Misalnya, Pesantren Maslakul Huda di Pati yang telah menginisiasi dan menggerakkan unit pengembangan swadaya masyarakat dengan konsentrasi kepada bidang perekonomian dan kesehatan. $^{7}$ Pesantren Sidogiri di Pasuruan yang mengembangkan model koperasi syari'ah dan bank syari'ah dengan omset yang mengagumkan. Pesantren Darul Fallakh di Bogor yang populer dengan teknologi kultur jaringan (tissue culture) ${ }^{8}$ dan Pesantren alIttifaq di Bandung yang lebih populer dengan sebutan pesantren agrobisnis. ${ }^{9}$ Atas keberhasilannya, kajian tentang pesantrenpesantren ini pun telah ditemukan dalam berbagai bentuk, baik buku, jurnal, tesis bahkan disertasi.

Di sisi lain, tulisan yang mengkaji tentang pesantren yang sedang melakukan rintisan pengembangan ekonomi, meski dalam skala kecil namun dinilai potensial untuk berkembang menjadi lebih besar berdasarkan sumber daya yang dimilikinya tampak belum banyak ditemukan. Padahal pesantren ini sejatinya memperoleh dukungan akses publikasi dan sosialisasi yang lebih luas. Pesantren ini membutuhkan jaringan yang kuat agar dapat membangun kemitraan yang menguntungkan dengan berbagai pihak. Dalam hal ini, gagasan dan upaya yang dikembangkan oleh PP. Ath-Thohariyyah di Pandeglang yang tetap konsisten kepada pendalaman kitab kuning sebagai khazanah intelektual klasik, sekaligus memberikan pendidikan keterampilan bagi para santrinya adalah bahasan yang penting untuk dikaji. Hampir seribu santri PP. Ath-Thohariyyah mengkaji kitab kuning, mulai dari tingkat dasar sampai dengan tingkat lanjut dalam berbagai disiplin keilmuan. Di samping itu, para santri juga

${ }^{7}$ Sahal Mahfudh. (1987). Pengembangan Masyarakat oleh Pesantren: Antara Fungsi dan Tantangan, dalam Pesantren, Nomor 2, Volume IV.

${ }^{8}$ Nunu Ahmad An-Nahidl. (2017). Pesantren Darul Fallakh: Gagahnya Santri Menjadi Petani, dalam "Murtadlo, dkk. Top 10 Ekosantri Pionir Kemandirian Pesantren. Jakarta: Litbangdiklat Press, h. 77-99.

${ }^{9}$ Qowa'id. (2007). KH Fuad Affandi: Spirit Pemikiran Salaf, Bentuk Pesantren Agrobisnis, dalam Pemikir Pendidikan Islam: Biografi Sosial Intelektual. Ed. Choirul Fuad Yusuf. Jakarta: Pena Citasatria, h. 325-358. belajar mengolah dan mengelola sejumlah produk keterampilan.

Kajian mendalam terhadap PP. AthThohariyyah dipandang penting dilakukan untuk mendeskripsikan penyelenggaraan pendalaman ilmu agama dan pengembangan keterampilan pada pesantren tersebut. Dari deskripsi tersebut, diperoleh sebuah gambaran yang mendalam tentang aspek input, proses dan output pada pendalaman ilmu agama, serta jenis keterampilan, kemitraan, dan nilai manfaat pada pengembangan keterampilan di pesantren tersebut. Artinya, terdapat dua fokus utama dalam penelitian ini, yaitu: pertama, tentang penyelenggaraan pendalaman ilmu agama dan kedua, tentang pengembangan keterampilan di PP. Ath-Thohariyyah.

Tujuan penelitian ini secara umum adalah menghimpun data informasi tentang pendalaman ilmu agama dan pengembangan keterampilan di PP. Ath-Thohariyyah. Sedangkan secara khusus, berupaya melakukan telaah secara mendalam terhadap sejumlah aspek, yaitu input, proses dan output pada pendalaman ilmu agama, serta jenis keterampilan, kemitraan, dan nilai manfaat dalam pengembangan keterampilan di PP. AthThohariyyah.

\section{METODOLOGI PENELITIAN}

Penelitian ini menggunakan pendekatan kualitatif. ${ }^{10}$ Penelitian dilakukan di Pondok Pesantren Ath-Thohariyyah Pandeglang Banten. Instrumen utama dalam penelitian ini adalah peneliti itu sendiri. ${ }^{11}$ Jenis data yang dikumpulkan merupakan data kualitatif. Sumber datanya berupa kata-kata dan tindakan orang yang diamati atau yang diwawancarai, dan selebihnya adalah data yang berupa dokumen. ${ }^{12}$

Untuk memperoleh data yang diperlukan, maka digunakan beberapa teknik pengumpulan data, yaitu: 1) wawancara mendalam; 2) observasi partisipasi; 3) studi dokumentasi, dan 4) triangulasi.

\footnotetext{
${ }^{10}$ Noeng Muhadjir. (1992). Metodologi Penelitian Kualitatif. Yogyakarta: Penerbit Rake Sarasin, h. 27-29.

${ }^{11}$ Sugiono. (2008). Metode Penelitian Pendidikan. Bandung: Alfabeta, h. 305-307.

${ }^{12}$ Moleong. (2007). Metodologi Penelitian Kuaitatif. Bandung: Remaja Rosdakarya, h. 157.
} 
Wawancara dengan pihak Kementerian Agama Pandeglang dilakukan untuk mengetahui kebijakan secara umum tentang pembinaan pendidikan keagamaan di wilayah Kabupaten Pandeglang. Wawancara dengan tokoh pendidikan dan ormas Islam dilakukan untuk memperoleh informasi tentang sejarah dan perkembangan pendidikan di wilayah Banten dan Pandeglang. Wawancara dengan pihak pengelola Pondok Pesantren AthThohariyyah, baik pengasuh utama maupun ustad dilakukan untuk mengkaji seluruh fokus penelitian dan setiap aspeknya; meliputi input, proses, dan output pendidikan, serta jenis keterampilan, kemitraan, dan nilai manfaat pada pengembangan keterampilan. Wawancara dengan santri dilakukan untuk mengkonfirmasi berbagai temuan terkait aktivitas keseharian para santri.

Observasi dilakukan untuk mengamati dan memahami secara langsung konteks data dalam keseluruhan situasi di pusat pendidikan, sehingga diperoleh pandangan yang holistik atau menyeluruh tentang pelaksanaan pendalaman ilmu agama dan pengembangan keterampilan.

Studi dokumentasi dilakukan dalam rangka memperoleh data tertulis tentang penyelenggaraan pendalaman ilmu agama dan pengembangan keterampilan, yaitu dokumen MoU, data statistik pendidikan, dokumen foto, SK yayasan, peraturan yayasan, SK Kementerian Agama, data profil yayasan, dan lain-lain.

Triangulasi, yaitu pengumpulan data yang bersifat menggabungkan dari berbagai teknik pengumpulan data dan sumber data yang ada, atau dapat dikatakan sebagai proses pengujian kredibilitas data, baik pada teknik maupun sumber data. ${ }^{13}$

\section{HASIL DAN PEMBAHASAN}

\section{Sekilas Profil Pengasuh}

Di tengah kehidupan masyarakat, tidak semua alumni pesantren menjadi ustad, apalagi kiai, selain tidak semua santri memang tidak ingin menjadi kiai. Bahkan, sesungguhnya tidak ada pesantren yang menjanjikan

\footnotetext{
${ }^{13}$ Sugiono. Op.Cit., h. 330.
}

lulusannya pasti menjadi kiai. Para pengasuh pesantren hanyalah melakukan ikhtiar dengan cara memberikan bekal ilmu agama yang memadai kepada para santrinya agar kelak mereka dapat bermanfaat, tidak hanya untuk dirinya sendiri, bahkan juga lingkungan yang lebih luas. Pikiran-pikiran ini yang melatarbelakangi Umi Eha, ketika mengembangkan Pondok Pesantren Ath-Thohariyyah di Kampung Pasar Sodong, Desa Sindanghayu, Kecamatan Saketi, Kabupaten Pandeglang, Propinsi Banten. ${ }^{14}$

Hj. Eha Shofa Zulaeha, demikian nama lengkapnya, adalah sosok yang luar biasa. Jika pesantren pada umumnya dikelola oleh seorang kiai, maka pesantren yang letaknya sekitar $23 \mathrm{~km}$ dari alun-alun Kota Pandeglang ini, justru didirikan dan diasuh oleh seorang ibu nyai tamatan sebuah pesantren di Kota Tasikmalaya, Jawa Barat. Sejak kecil, Umi Eha sudah ditempa dengan pendidikan agama yang sangat memadai. Selepas tamat dari pendidikan Tsanawiyah, Umi Eha menempuh pendidikan diniyah di PP. Ath-Thohariyyah Tasikmalaya yang diasuh KH Musaddad Faried.

Tahun 1995, Umi Eha menyelesaikan pendidikan pesantrennya di Tasikmalaya. Selepas nyantri, dia tidak berdiam diri di rumah, melainkan segera mengembangkan ilmu yang dimilikinya dengan mengajar di Madrasah Ibtidaiyah, RA, dan TPQ di sekitar tempat tinggalnya. Selanjutnya, Umi Eha mulai membuka pengajian di tempat tinggalnya. Para santri pun mulai berdatangan mengikuti pengajian yang diselenggarakannya. Selanjutnya, tahun 1999 Umi Eha mulai merintis pembangunan sejumlah sarana pesantren dengan biaya sendiri. Dana itu Umi Eha peroleh dari hasil penjualan tanah pribadi miliknya seluas $2 \mathrm{Ha}$ di kawasan Cibaliung dekat Ujung Kulon.

\footnotetext{
${ }^{14}$ Wawancara dengan Umi Eha, Pengasuh PP. Pesantren Ath-Thohariyyah, Kampung Pasar Sodong, Desa Sindanghayu, Kecamatan Saketi, Kabupaten Pandeglang, pada Kamis, 24 Mei 2014.
} 
Tabel 1. Data Statistik Peserta Didik PP. Ath-Thohariyyah Tahun 2017

\begin{tabular}{|c|l|c|c|c|}
\hline No & \multicolumn{1}{|c|}{ Satuan Pendidikan } & Lk & Pr & Jumlah Total \\
\hline 1 & Santri Salafi Mukim & 175 & 310 & 485 \\
\hline 2 & Santri Salafi non Mukim & 19 & 8 & 27 \\
\hline 3 & Raudlatul Athfal & 25 & 31 & 56 \\
\hline 4 & TPQ dan MDA & 73 & 112 & 185 \\
\hline 5 & Wustho/ Paket B & 31 & 34 & 65 \\
\hline 6 & Paket C & 23 & 38 & 61 \\
\hline 7 & SLB & 21 & 24 & 45 \\
\hline 8 & Majelis Taklim Muslimat & - & 192 & 192 \\
\hline \multicolumn{2}{r}{ Jumlah } & 292 & 689 & 990 \\
\hline
\end{tabular}

Sumber: Data Dokumentasi Sekretariat PP. Pesantren Ath-Thohariyyah Tahun 2017

Jika bukan satu-satunya, Umi Eha mungkin satu dari sedikit orang yang menginisiasi pendirian pesantren salafiyah ${ }^{15} \mathrm{di}$ Propinsi Banten dimana hampir seluruh santrinya sebanyak 900 orang berkonsentrasi kepada pengajian kitab kuning, mulai dari tingkat dasar, menengah hingga kitab kuning tingkat tinggi dari sisi bobot. Tidak berhenti di situ. Nilai plus lembaga pendidikan keagamaan ini pun semakin luar biasa, ketika Umi Eha mulai mengembangkan pendidikan keterampilan bagi seluruh santri yang mukim. Motivasi diselenggarakannya pendidikan keterampilan bagi para santri ini didasari alasan bahwa alumnus pesantren dipandang perlu memiliki keahlian atau kecakapan tertentu di luar bidang keilmuan yang digelutinya setiap hari.

\section{Pondok Pesantren Ath-Thohariyyah}

PP. Ath-Thohariyyah secara resmi berdiri pada tahun 2001 di atas tanah milik pribadi seluas $12.449 \mathrm{~m}^{2}$. Bangunan fisik pesantren yang berdiri di atas tanah tersebut seluas $3.511 \mathrm{M}^{2}$ terdiri dari beberapa bagian,

\footnotetext{
${ }^{15}$ Istilah salaf, salafi dan salafiyah tampaknya perlu dimaknai sesuai konteksnya. Dalam pengertian yang sederhana, pesantren salafiyah adalah satuan pendidikan Islam yang masih melestaraikan warisan ulama terdahulu (kitab turats) dan tradisi lokal. Secara sosiologis, pesantren salafiyah identik dengan pesantren tradisional. Lihat: Azyumardi Azra. "Pesantren: Kontinuitas dan Perubahan," dalam Nurcholish Madjid. Bilik-bilik Pesantren. Jakarta: Penerbit Dian Rakyat, h. Xxiv; Ahmad Rofi Usmani. 2016. Jejak-jejak Islam. Yogyakarta: Penerbit Bunyan, h. 312-313; Abdul Mughits. 2008. Kritik Nalar Fiqh Pesantren. Jakarta: Kencana, h. 117-130.
}

seperti asrama santri putra dan putri, perpustakaan, mushalla, ruang pengajian, ruang ketrampilan, ruang Poskestren, ruang tamu dan kantor. Selebihnya adalah tanah perkebunan, sawah dan kolam ikan.

Hingga saat ini, satuan pendidikan yang dikelola oleh PP. Ath-Thohariyyah adalah pendidikan salafiyah, Raudlatul Athfal, TPQ, Madrasah Diniyah Awaliyah, Program Wajar Dikdas tingkat Wushto, Program Paket C, SLB, dan Majelis Taklim Muslimat. Adapun jumlah santri/jamaah yang diasuhnya adalah sebagaimana dalam Tabel 1 .

Dari jumlah total sebanyak 990 santri dan jamaah pengajian yang mengikuti pendidikan di PP. Ath-Thohariyyah, tercatat sebanyak 473 santri yang mukim di pesantren. Selebihnya adalah mereka yang pulang pergi ke rumah masing-masing setelah menyelesaikan proses pembelajaran di pesantren. Santri mukim ini berasal dari berbagai daerah, seperti Palembang, Tangerang, Tasikmalaya, Karawang, Serang, Bogor, dan sebagian besar dari Pandeglang. Sementara jumlah tenaga kependidikan yang aktif terlibat dalam proses pembelajaran sehari-hari di PP. AthThohariyyah sebanyak 50 orang.

\section{Pendalaman Ilmu Agama dengan Kitab Kuning}

Suasana sebuah pesantren sudah kuat terasa sejak memasuki pintu gerbang depan. Para santri PP. Ath-Thohariyyah hilir mudik 
menggenggam kokoh kitab kuning. ${ }^{16}$ Pukul 10.00 pagi, mereka baru saja selesai mengikuti kegiatan pembelajaran untuk pagi hari. Ada pemandangan yang unik. Dalam budaya pesantren tradisional, cara santri memegang kitab kuning seringkali berbeda dengan memegang buku pada umumnya. Santri menaruh penghormatan khusus untuk karya para ulama ini. Mereka mengapit kuat kitab kuning yang dipegangnya dengan mengangkatnya dan meletakkannya setengah dada, berbeda dengan membawa buku pada umumnya.

Pukul dua pagi, para santri sudah diingatkan oleh bel penanda yang membangunkan kegiatan tidur mereka. Selanjutnya, bersimpuh dan bermunajat kepada Allah swt dengan melaksanakan shalat tahajud. Santri dibiasakan untuk bangun di pertengahan malam. Keheningan malam adalah waktu paling tepat untuk memohon do'a dan permintaan apapun kepada Allah SWT. Kegiatan tengah malam ini tidak sederhana. Memerlukan kesiapan hati dan kesungguhan batin untuk mengikutinya. Pesantren pun tidak mewajibkannya untuk untuk santri baru. Meski hampir separuh jumlah santri, terutama santri senior bangkit dari tidurnya dan mengambil air wudlu untuk shalat malam. Sementara khusus untuk malam Jumat, seluruh santri dibangunkan pukul tiga pagi, dan selanjutnya bersama-sama shalat tahajud; shalat tasbih, shalat istikharah, dll. Kemudian mereka kembali beristirahat sampai waktu subuh tiba.

Kira-kira sepuluh menit sebelum adzan subuh berkumandang, para santri sudah memenuhi barisan shaf untuk melaksanakan shalat subuh berjamaah. Shalat dilaksanakan di aula pesantren, karena pesantren belum memiliki masjid. Hampir tidak ada santri yang tertinggal dalam kegiatan paling awal di setiap pagi hari itu. Sebab setelah shalat, mereka akan memulai kegiatan rutin harian. Selepas membaca wirid bersama-sama, para santri

${ }^{16}$ Di dalam Peraturan Menteri Agama RI Nomor 13 Tahun 2014 tentang Pendidikan Keagamaan Islam, disebutkan bahwa kitab kuning adalah kitab keislaman berbahasa Arab yang menjadi rujukan tradisi keilmuan Islam di pesantren. Daftar kitab kuning yang digunakan di pesantren, antara lain dikaji dalam Martin van Bruinessen. 1995. Kitab Kuning, Pesantren dan Tarekat. Bandung: Penerbit Mizan, h. 17-172. membaca al-Qur'an dengan cara sorogan. ${ }^{17}$ Sorogan dilakukan terutama untuk menghafal sejumlah surat di dalam al-Qur'an yang wajib dihafal. Saat sorogan, biasanya santri dibagi ke dalam enam kelompok. Masing-masing kelompok diajar oleh satu orang ustad. Selain diajarkan tentang tata cara membaca al-Qur'an, santri juga diajarkan hukum tajwidnya. ${ }^{18}$

Pukul enam pagi bel dibunyikan. Bel ini menandakan dimulainya pengajian kitab kuning. Fathul Muin menjadi kitab pertama yang dipelajari santri dalam kegiatan harian. Kitab fiqh Syafi'i karya Zainuddin Abdul Aziz al-Malibary ini sangat populer di dunia pesantren. Kitab ini seringkali dimasukkan ke dalam tingkatan menengah dari sisi bobot keilmuan dan kedalaman isinya. Mengingat kedudukannya yang sangat penting, maka dalam tradisi pesantren, seorang santri belum dianggap pantas menjadi calon kiai, jika dia belum pernah belajar dan mengaji kitab Fathul Muin. Kitab ini dinilai sebagai standar minimal kompetensi akademik seorang kiai. ${ }^{19}$

Kitab Fathul Muin diajarkan langsung oleh Umi Eha untuk seluruh santri. Umi Eha berhadapan langsung dengan santri putri di aula bawah, sementara santri putra di aula atas. Meski berbeda ruangan, suara Umi Eha terdengar jelas berkat bantuan speaker. Umi Eha sendiri memantau langsung kegiatan para santri putra dalam pengajian itu melalui layar CCTV. Ini pemandangan yang unik dan terbilang maju untuk ukuran pesantren salafiyah. Selesai pengajian, para santri sarapan pagi dan shalat dhuha.

Pukul 08.30 seluruh santri kembali mengikuti pengajian. Mereka dibagi ke dalam tiga kelompok kelas, yaitu kelas Jurumiyyah,

17،Sorogan adalah metode belajar dimana santri membaca langsung kitab yang dipelajari di hadapan kiai, dan memberikan arti pada setiap kata atau kalimat yang dibaca. Kiai mengawasi bacaan santri dan akan mengingatkan jika terdapat kekeliruan dalam bacaannya. Banyak pendapat menyebutkan bahwa metode ini dipandang lebih efektif dalam memahami kitab kuning, karena mendorong santri menjadi lebih aktif dalam pembelajaran." Wawancara dengan Drs. KH. Moh. Suhri Utsman, tokoh masyarakat, Pengurus MUI dan Baznas Propinsi Banten, pada Rabu, 2 Agustus 2017.

18 Wawancara dengan Elif Lathifah, Bendahara PP. Ath-Thohariyyah, Rabu, 24 Mei 2017.

19 Wawancara dengan Ustad Bahruddin, Pengasuh PP. Ath-Thohariyyah, Selasa, 1 Agustus 2017. 
kelas Imrithi, dan kelas Alfiyah. Penggunaan nama kitab bagi ketiga kelas ini bukan berarti ketiga kitab itu saja yang dikaji, melainkan lebih menunjukkan kepada jenjang kelas kitab yang akan dipelajari santri. Kelas Jurumiyyah adalah kelas dasar dimana kitab-kitab yang dipelajari santri pun adalah kitab tingkat dasar dalam berbagai bidang keilmuan. Wali kelas Jurumiyyah adalah Umi Eha. Kelas Imrithi adalah kelas menengah dimana kitab yang dipelajari di kelas ini adalah kitab-kitab pada tingkatan menengah. Wali kelas Imrithi adalah Ustad Bahruddin. Sementara kelas Alfiyah adalah jenjang kelas atas. Kitab-kitab yang dipelajari para santri pun merupakan kitab pada tingkatan atas. Wali kelas Alfiyah adalah Ustad Isnain Humaini.

Mulai pukul 10.00 pagi, para santri diberikan waktu istirahat. Di sela-sela waktu ini koperasi pesantren dibuka. Koperasi yang dikelola para santri ini memang tidak dibuka setiap saat. Koperasi menyediakan kebutuhan santri sehari-hari, seperti alat cuci, alat mandi, alat tulis dan berbagai makanan ringan. Santri biasanya mencukupi kebutuhannya dengan belanja di koperasi saja. Mereka tidak diperbolehkan keluar dari lingkungan pesantren. Khusus santri putra, memang diizinkan keluar pesantren hanya untuk shalat maghrib berjamah di Masjid al-Mubarok. Selain untuk tujuan shalat, mereka diarahkan untuk bisa berbaur dengan masyarakat di sekeliling pesantren. Masjid al-Mubarok letaknya berseberangan dengan tembok gerbang masuk pesantren.

Saat waktu Dzuhur tiba, aula pesantren sudah dipenuhi oleh para santri yang menunaikan shalat sunnah qabliyyah. Amalan sunnah sangat dianjurkan untuk dilakukan. Pesantren ingin menekankan pola pembiasaan, apalagi untuk shalat berjamaah. Karena itu, ada sangsi khusus bagi santri yang tidak shalat berjamaah. Santri yang dikenai sangsi, wajib berdiri di depan kelas selama pengajian Fathul Muin.

Selesai shalat Dzuhur berjamaah, seluruh santri menikmati makan siang dengan 'berjamaah' pula. Santap siang bersama-sama ini dibagi ke dalam beberapa kelompok. Biasanya satu kelompok terdiri dari 6-7 orang. Masing-masing menikmati hidangan di atas sebuah nampan atau wadah berukuran cukup besar. Inilah saat yang paling berkesan menjadi seorang santri. Suasana kebersamaan ini adalah pengalaman yang sulit dilupakan. Seluruh hidangan disiapkan oleh santri sendiri yang diberi tugas secara bergiliran. Untuk kebutuhan belanja masakan, setiap santri menyerahkan iuran perbulan sebesar 100 ribu rupiah untuk tiga kali makan setiap hari.

Siang hari, para santri mengaji kitab kuning sesuai kelas masing-masing. Kitab yang dipelajari adalah Akhlak lil Banin, Taysirul Khalaq, Washiyatul Mustafa, Jurumiyyah, Awamil, dan Nihayatuz Zain. Sementara sore harinya, setelah shalat Ashar, mereka mempelajari Tafsir Jalalain, Safinatun Najah, Riyadul Badi'ah dan Jurumiyyah. Seluruh pengajian berakhir menjelang maghrib.

Shalat maghrib berjamaah dilakukan santri putri di aula pesantren, sementara santri putra di Masjid al-Mubarok. Selesai shalat maghrib, kegiatan santri berbeda-beda. Pada malam Jum'at, para santri membaca Surat Yasin bersama-sama, termasuk membaca Yasin Fadlilah di minggu pertama bulan hijriyah. Pada hari Jumat, santri kelas Jurumiyah dan Imrithi melakukan sorogan hafalan al-Qur'an surat-surat pendek dan suratsurat penting seperti Waqiah, al-Mulk, dan Yasin. Sementara untuk kelas Alfiyah, mengaji kitab Jauharul Maknun.

Pada malam minggu, kegiatan santri adalah muhadlarah atau latihan berpidato. Sementara hari Minggu dan Senin adalah pengajian umum. Kitab yang dibaca adalah Mawahibush Shamad. Pengajarnya adalah Umi Eha. Pengajian ini juga diikuti oleh santri nonmukim atau mereka yang tinggal di luar pesantren. Sementara hari Selasa dan Rabu adalah sorogan al-Qur'an setiap kelas, baik kelas Jurumiyah, Imrithi maupun kelas Alfiyah.

Bada shalat Isya berjamaah, kegiatan santri berbeda-beda pada setiap harinya. Pada hari Jumat dan Minggu, untuk kelas Jurumiyah mengaji kitab Khulashah Nurul Yaqin yang diajarkan oleh Umi Eha, sementara untuk kelas Imrithi dan Alfiyah, mengaji kitab Sullamut Taufiq yang diajarkan oleh Ustad Bahruddin. Sedangkan untuk hari Senin dan Selasa, para 
santri mengaji kitab sharaf; Tashrifan, Matan Bina, Kailani dan Taftazani, sesuai tingkatannya. Pada hari Rabunya, santri putra berlatih silat yang diajarkan oleh santri senior, dan untuk santri putri melakukan latihan marawis.

Pada hari Kamis ba'da Isya, para santri mengaji kitab Muhtarul Hadits untuk kelas Imrithi dan Alfiyah, dan membaca kitab Barzanzi untuk santri kelas Jurumiyah. Seluruh kegiatan harian ini berakhir pukul 22.00 malam hari. Selanjutnya mereka diwajibkan beristirahat. Kegiatan harian santri ini berjalan dari waktu ke waktu sampai mereka menyelesaikan masa pendidikan di pesantren. ${ }^{20}$

\section{Melatih Santri Mandiri dengan Keterampilan}

Wilayah Pandeglang sebelah Barat, mulai Bojong, Saketi, Menes hingga Labuan dan sekitarnya merupakan daerah sentra penghasil emping atau keceprek yang bahan bakunya adalah buah melinjo. Buah dan daun melinjo yang biasa dibuat bahan sayur asem ini memang banyak ditemukan pohonnya di sekitar wilayah tersebut. Belakangan meski pohon melinjo masih cukup banyak ditemukan di pekarangan rumah penduduk, namun buah yang dihasilkannya semakin berkurang. Ini pula yang dirasakan Umi Eha tentang sulitnya memperoleh bahan baku keceprek super.

Salah satu dari tiga jenis keterampilan yang dikembangkan oleh santri PP. AthThohariyyah adalah tata boga dengan konsentrasi kepada pembuatan keceprek super. Sedangkan dua jenis lainnya adalah pembuatan abon lele dan tata busana. Biasanya, orang tidak membedakan jenis keceprek yang ada di pasaran, dan tidak tahu persis keunggulan pada setiap jenisnya. Padahal ada yang disebut dengan keceprek super. Keceprek jenis super tentu berbeda dengan keceprek pada umumnya. Keceprek ini diolah dari bahan baku pilihan. Itulah sebabnya kualitas keceprek dinilai super.

Menurut Umi Eha, ide membuat keceprek super tidak disengaja. Awalnya, dia memperoleh oleh-oleh keceprek dari salah satu orangtua santri. Bentuknya berbeda dengan

${ }^{20}$ Wawancara dengan Elif Lathifah, Bendahara PP. Ath-Thohariyyah, pada Rabu, 24 Mei 2017. keceprek pada umumnya. Maka dia meminta informasi tentang jenis keceprek yang disebut super itu. Bahkan dia mengajak kerjasama dan mengundang orangtua santri itu untuk berbagai ilmu dengan mengajarkan cara membuat keceprek super kepada para santri di pesantren. ${ }^{21}$

Maka sejak tahun 2010, para santri memperoleh keterampilan mengolah keceprek super. Keceprek super bahan bakunya pilihan, dan berasal dari buah melinjo yang baru dipetik, bukan stok lama. Bentuknya lebih besar ketimbang biasanya. Buah melinjo yang sudah dipetik lama dan bentuknya kecil tidak bisa diolah menjadi keceprek super. Salah satu ciri keceprek super adalah bentuknya akan mengembung dan cenderung bulat ketika digoreng. Keceprek ini lebih renyah waktu dimakan. Sementara keceprek biasa, bentuknya agak kempes dan keras.

Bahan baku untuk membuat keceprek super ternyata tidak mudah diperoleh. Umi Eha sendiri merasakan adanya kendala. Selama ini dia menjalin kerjasama dengan sejumlah pengepul di Pasar Sodong yang menampung sejumlah hasil pertanian. Posisi Pasar Sodong berseberangan langsung dengan komplek pesantren. Dia meminta kepada pengepul untuk memisahkan buah melinjo yang kualitasnya bagus, dan membelinya untuk kebutuhan produksi keceprek. Di samping itu, dia juga bekerjasama dengan orangtua santri yang mayoritas petani. Melalui anak-anaknya, mereka diminta untuk menjual buah melinjo berkualitas super kepada pesantren, dan selanjutnya akan diolah oleh para santri. ${ }^{22}$ Umi Eha pun menyiapkan sebuah tempat khusus di bagian belakang komplek pesantren. Tempat ini diperuntukkan sebagai dapur produksi yang dilengkapi dengan sejumlah alat yang dibutuhkan. ${ }^{23}$

Namun demikian, kegiatan produksi keceprek super sifatnya temporal, tidak rutin. Tergantung adanya bahan baku yang cukup, dan pesanan yang datang. Faktanya, mencari

\footnotetext{
${ }^{21}$ Wawancara dengan Umi Eha, Pengasuh PP. Ath-Thohariyyah, pada Kamis, 24 Mei 2014.

${ }^{22}$ Wawancara dengan Umi Eha, Pengasuh PP. Ath-Thohariyyah, pada Rabu, 24 Mei 2017.

${ }^{23}$ Data observasi di PP. Ath-Thohariyyah pada Rabu, 24 Mei 2017.
} 
buah melinjo dengan kualitas baik ternyata tidak mudah. Ketika bahan baku sedang kosong, maka kegiatan produksi tidak berjalan. Tetapi jika bahan bakunya ada, keceprek super akan tetap diproduksi, meski tidak ada pesanan. Kemudian, keceprek itu dititipkan di sejumlah warung dan toko. ${ }^{24}$ Untuk menjaga mutu produksi, Umi Eha mendaftarkan olahan para santri ini ke Dinas Kesehatan, dan memperoleh P-IRT atau Pangan Industri Rumah Tangga. Tanda sertifikasi sebagai izin produksi untuk skala rumahan ini dikeluarkan oleh Dinas Kesehatan Kabupaten Pandeglang sejak tahun 2011, dan harus perbaharui setiap lima tahun.

Selain keceprek super, keterampilan lain yang dikembangkan para santri adalah abon lele. Keterampilan mengolah abon lele dimulai pada tahun 2014. Seperti halnya keceprek super, usaha abon lele juga pernah menghadapi kendala bahan baku. Namun cerita sulitnya memperoleh ikan lele itu berakhir setelah para santri justru membudidayakan ikan lele sendiri. Di bagian belakang area pesantren, terdapat sejumlah kolam ikan ukuran sedang yang dikelola para santri. Tidak hanya kolam ikan lele, melainkan juga gurame dan nila. ${ }^{25}$

Para santri secara bergantian mencari daun talas dan keong emas untuk pakan ikan. Tidak ada yang diwajibkan. Semuanya atas kesadaran sendiri. Beruntung, belum lama ini pesantren memperoleh hibah dua buah mesin pembuat pakan ikan. Sama halnya keceprek super, abon lele tanpa pengawet hasil olahan santri ini dibuat berdasarkan pesanan. Tidak terus menerus berproduksi. Pesantren belum membangun jaringan kerjasama secara resmi dan luas dengan banyak pihak. Selama ini hanya memanfaatkan kontak-kontak terbatas, termasuk dengan alumni pesantren yang tersebar di berbagai daerah.

Produk abon lele telah memperoleh P-IRT dari Dinas Kesehatan Kab. Pandeglang dan sertifikasi halal dari MUI sejak tahun 2015. Produk abon lele sering diikutkan dalam setiap pameran yang diselenggarakan oleh pihak Pemda Kabupaten Pandeglang dan Propinsi

\footnotetext{
${ }^{24}$ Wawancara dengan Elif Lathifah, Pengurus PP. Ath-Thohariyyah, pada Rabu, 24 Mei 2017.

${ }^{25}$ Data observasi di PP. Ath-Thohariyyah pada Rabu, 24 Mei 2017.
}

Banten. Pameran ini jelas merupakan media sosialisasi dan publikasi yang sangat efektif untuk mengenalkan produk para santri kepada masyarakat luas.

Keterampilan lainnya yang dipelajari santri adalah jenis yang lebih banyak dilakukan oleh santri putri, seperti menjahit, tata rias, rias pengantin, membuat bros, membuat bunga hiasan, serta membuat aksesori hiasan pada berbagai wadah atau parsel. Untuk rias pengantin, misalnya. Umi Eha mendatangkan ahlinya untuk mengajar para santri. Biayanya menggunakan dana pribadi Umi Eha sendiri, bukan dari pesantren. Hasilnya, banyak santri putri yang terampil merias. Mereka pun wajib melatih santri dari generasi di bawahnya. Sebab tidak mungkin pesantren selalu mendatangkan guru dari luar yang memang tidak murah biayanya. Dengan cara demikian, ilmu dan keahlian berkembang sedemikian rupa. Generasi pertama dididik dan kemudian melatih generasi kedua, demikian seterusnya. Intinya, seluruh santri memiliki kesempatan dan pengalaman untuk belajar keterampilan.

Keterampilan lainnya adalah menjahit. Keterampilan ini berhubungan langsung dengan kebutuhan harian, maka menjadi pilihan favorit santri putri. Saat ini pesantren memiliki lima buah mesin jahit, ditambah mesin bordir. Mesin ini dipergunakan seluasluasnya oleh para santri yang mengambil keterampilan menjahit. ${ }^{26}$ Pesantren memiliki banyak santri yang terampil menjahit. Bahkan kemampuan mereka dimanfaatkan untuk membuat sejumlah pakaian seragam atau kostum, seperti seragam marawis, seragam hadrah, seragam qasidah, dan seragam taritarian. Pengadaan sejumlah kostum acara ini muncul dalam pikiran Umi Eha setelah beberapa kali penyelenggaraan acara di pesantren, ternyata santri mengalami kerepotan sendiri dalam menyiapkan seragam acara. Kini pesantren memiliki sejumlah pakaian seragam atau kostum. Pakaian tersebut tidak saja digunakan untuk kebutuhan santri sendiri, bahkan disewakan kepada pihak lain. Dari lima buah model kostum yang dimiliki, masingmasing kostum tersebut tersedia untuk satu kelompok/grup dengan jumlah personel

${ }^{26}$ Data observasi di PP. Ath-Thohariyyah pada Rabu, 24 Mei 2017. 
sebanyak 12 orang. Desainnya disesuaikan dengan tingkat usia, yaitu kostum khusus ibuibu, remaja, dan anak-anak.

\section{Upaya untuk Maju dan Kompetitif}

Konsepsi al-Qur'an jelas mendiskusikan perihal kesejahteraan sosial ekonomi, sebagai bagian dari kebahagiaan di dunia dan kebahagiaan di akhirat. Dalam hal ini, pencapaian hidup yang berkualitas adalah keseimbangan antara dunia dan akhirat (QS 17:72). Dalam hal ini, manusia sebagai subyek ekonomi didorong untuk terus berupaya sesuai dengan kadar potensinya. Menurut Sahal, dengan mengutip sebuah Hadis yang artinya; "Bekerja untuk memenuhi kebutuhan ekonomi adalah wajib, setelah kewajiban yang lain." Interpretasi terhadap Hadis ini akan melahirkan kelompok manusia produktif dan bersumberdaya tinggi, sekaligus sebagai inti perekonomian. Allah menyiapkan sarana dan sumberdaya alam, maka untuk mengolahnya dibutuhkan manusia yang produktif. ${ }^{27}$

Internalisasi konsep manusia produktif ini tergambar dalam dalam ungkapan Elif Lathifah, salah seorang santri PP. AthThohariyyah menuturkan; ${ }^{28}$

"Betapa luar biasanya ilmu dan pengalaman yang diperoleh selama kami 'nyantri' di PP. Ath-Thohariyyah. Apa yang diperoleh santri benar-benar menjadi bekal yang sangat berguna, tidak saja untuk pribadi santri, bahkan juga masyarakat. Di pesantren, kami dididik untuk memanfaatkan ilmu yang dimiliki dengan mengajarkannya kepada masyarakat luas. Kami punya bekal ilmu dan kami pun punya bekal keterampila".

Apa yang disampaikan salah seorang santri ini, bisa jadi hanya sebagian kecil ekspresi dari sekian banyak ungkapan perasaan yang ada pada sebagian besar santri. Namun demikian, mungkin saja sudah dapat mewakili

\footnotetext{
${ }^{27}$ Sahal Mahfudh. (1994). Nuansa Fiqh Sosial. Yogyakarta: LkiS, h.

${ }^{28}$ Elif Lathifah adalah tamatan Program Paket C angkatan pertama. Sejak tahun 2004, dia belajar di pesantren. Saat ini belajar di Fakultas Agama Prodi Syariah, Universitas Mathla'ul Anwar, Pandeglang. Santri penerima beasiswa ini ikut mengabdi di pesantren sebagai pengurus harian. Wawancara dengan Elif Lathifah, pada Selasa, 1 Agustus 2017.
}

pandangan umum mereka tentang pesantren tempat mereka mengais ilmu dan pengetahuan itu. Ada keyakinan yang dalam dan rasa percaya diri yang kuat tentang masa depan yang akan mereka jalani setelah menamatkan pendidikan di pesantren.

Akumulasi dua keahlian yang diperoleh santri, yaitu keahlian dalam bidang ilmu agama dan keahlian dalam bidang keterampilan ternyata dapat menumbuhkan motivasi yang luar biasa pada diri santri. Pertama, kesadaran untuk menimba ilmu agama di pesantren menandakan bahwa sejak awal para santri sangat meyakini pentingnya nilai pengetahuan tentang agama yang sedang mereka pelajari. Tholhah membagi dua periode sistematika mempelajari ajaran agama (Islam). Pertama, pra kodifikasi deskriptif dimana umumnya orang belajar agama dengan cara; mendengarkan keterangan guru, mengikuti petunjuk, perintah dan nasehat, dan istifta (meminta keterangan atau penjelasan hukum mengenai sesuatu hal). Kedua, pasca kodifikasi deskriptif dimana orang belajar agama menggunakan buku-buku agama. ${ }^{29}$ Kedua sistematika belajar agama tersebut, tentu dilakukan oleh para santri PP. AthThohariyyah. Nilai lebihnya, para santri juga memiliki pemahaman yang kuat bahwa kegiatan belajar agama di pesantren memiliki nilai ibadah. ${ }^{30}$

Kedua, tumbuhnya sikap mandiri dan rasa tanggungjawab untuk membekali diri dengan berbagai kemampuan yang membuat para santri merasa siap menghadapi kehidupan sosial di tengah masyarakat setelah menyelesaikan pendidikan di pesantren. Bagaimanapun, semangat dan daya juang untuk bertahan dalam kehidupan riil di tengah masyarakat adalah faktor penting yang niscaya dimiliki oleh tamatan lembaga pendidikan manapun. Faktanya, seringkali lulusan pendidikan tinggi pun bahkan dengan spesialisasi keilmuan tertentu yang semestinya memiliki kepercayaan diri yang kuat untuk mengembangkan dan menerapkan ilmu yang

\footnotetext{
${ }^{29}$ Muhammad Tholhah Hasan. (2005). Prospek Islam dalam Menghadapi Tantangan Zaman. Jakarta: Lantabora Press, h. 220-221

${ }^{30}$ Wawancara dengan Ustad Bahruddin, Pengasuh PP. Ath-Thohariyyah, pada Selasa, 1 Agustus 2017.
} 
dimilikinya, justru tampak gagap ketika dihadapkan kepada tantangan kehidupan sosial yang sesungguhnya. Persoalannya, selembar ijazah pendidikan tinggi tidak lagi menjadi jaminan kemudahan untuk memperoleh pekerjaan.

Kementerian Ketenagakerjaan RI. mencatat cukup tingginya angka pengangguran untuk tingkat pendidikan menengah ke atas (sarjana) tahun 2017. Selain itu jumlah kompetensi tenaga kerja berusia produktif sebesar 131,5 juta orang, dengan 79 juta orang atau kurang lebih $60 \%$ berpendidikan hanya di tingkat SMP. Menurut Dirjen Pembinaan Pelatihan dan Produktivitas Kerja, Kemenaker RI, Bambang Satrio Lelono, jika dilihat secara nasional angka pengangguran mencapai 7 juta jiwa atau 5,33\%. Angka itu merupakan pengangguran terbuka artinya penggangguran yang sama sekali tidak bekerja. Selain itu, terdapat beberapa faktor yang sering dihadapi di Indonesia, yaitu terbenturnya kualitas SDM dengan dunia kerja. Pertama, yaitu miss match atau ilmu yang dipelajari selalu berbeda dengan kebutuhan dunia kerja. Kedua, under qualified atau lulusan sarjana tapi kemampuan tidak menunjukan sarjananya sehingga pekerjaan yang didapat berada di level bawah. ${ }^{31}$

Dekan Fakultas Fisipol UGM Erwan Agust Purwanto menuturkan, setiap tahun ada penambahan pengangguran terdidik baru sekitar 66 ribu. Tahun 2017, jumlah pengangguran terdidik yang lulusan diploma dan sarjana di Indonesia, mencapai 1 juta jiwa. Erwan menjelaskan perlu ada terobosan untuk menekan bertambahnya pengangguran terdidik itu. "Seperti mendidik mereka untuk menjadi calon wirausahawan baru," katanya. Dia juga mengatakan saat ini Global Entrepreneurship Index (GEI) Indonesia berada di urutan ke 97 dari 136 negara. "Salah satu penyebab rendahnya GEI Indonesia adalah kecilnya persentase jumlah wirausaha. Pemicunya

31،Pengangguran di Indonesia Tinggi Karena Lulusan Perguruan Tinggi Terlalu 'Milih' Pekerjaan. http://m.tribunnews.com/nasional/2017/11/08/pengangg uran-di-indonesia-tinggi-karena-lulusan-perguruantinggi-terlalu-milih-pekerjaan?page $=3$. Diakses September 2018. rendahnya keterampilan dan etos kewirausahaan,', jelasnya ${ }^{32}$

Di sisi lain, harus diakui bahwa keberlangsungan pendidikan seringkali tidak berakar dari persoalan riil masyarakat dan tidak berorientasi pada problem masyarakat. Praktik pendidikan demikian disinyalir membuat orang sekolahan menjadi asing dan tidak mengenal persoalan yang sedang terjadi di sekitarnya. Bahkan tidak jarang, produk pendidikan justru melecehkan kehidupan dan pekerjaan masyarakat sekitar, misalnya petani. Padahal mayoritas masyarakat Indonesia ada di pedesaan yang notabene adalah masyarakat agraris. Hal ini terjadi karena anak didik lebih banyak diintervensi oleh praktik pendidikan model perkotaan dengan tipikal masyarakat industrial, dimana keluaran pendidikannya lebih percaya diri untuk memilih menjadi pegawai negeri sipil atau bekerja di perkantoran $^{33}$

Sebaliknya, PP. Ath-Thohariyyah justru berperan serta memperkecil rendahnya keterampilan dan etos wirausaha di kalangan peserta didik melalui berbagai kegiatan di pesantren. Bahkan dari sisi kualifikasi rintisan pengembangan ekonomi di pesantren, pilihan jenis keterampilan yang diambil oleh pesantren pun menunjukkan bahwa pengelola sangat memahami kebutuhan dan potensi lokal wilayah setempat. Keceprek, misalnya, adalah dihasilkan dari bahan baku buah melinjo yang banyak ditanam oleh para petani di wilayah Kabupaten Pandeglang. Demikian pula ikan lele dengan sumber air yang cukup melimpah di kawasan itu.

Artinya, dalam konteks pendidikan nonformal semisal PP. Ath-Thohariyyah, capaian ini menunjukkan perkembangan yang sangat positif dan luar biasa. Dua keahlian yang diperoleh santri tidak saja menunjukkan karakteristik pesantren, bahkan dapat dianggap sebagai keunggulan kompetitif (competitive advantage) pada pesantren itu. Artinya, kajian kitab kuning dan keterampilan adalah

\footnotetext{
32،Jumlah Pengangguran Terdidik, Ya Ampun!" Lihat: https://m.jpnn.com/news/jumlah-pengangguranterdidik-ya-ampun. Diakses 3 September 2018.

${ }^{33}$ Firdaus M Yunus. (2005). Pendidikan Berbasis Realitas Sosial - Paulo Freire YB Mangunwijaya. Yogyakarta: Logung Pustaka, h.98.
} 
kemampuan yang diperoleh santri berdasarkan karakteristik dan sumberdaya pesantren yang menjadi nilai lebih pesantren itu jika dibandingkan dengan pesantren yang lain. Meskipun tentu saja dalam beberapa aspek, keluaran pendidikan pesantren tidak dapat dibandingkan dengan pendidikan formal, mengingat input dan prosesnya tidak sama.

Namun demikian, apresiasi yang tinggi amat pantas diberikan. Di tengah masih kuatnya semangat para pengelola pesantren menyelenggarakan pendidikan formal dalam berbagai jenjang dan jenis pendidikan, PP. Ath-Thohariyyah tetap konsisiten mengokohkan konsentrasi pembelajarannya dalam kajian kitab kuning. Bahkan, jika trend penyelenggaraan pendidikan formal di pesantren, antara lain dilakukan dengan alasan untuk menarik minat peserta didik lebih banyak belajar di pesantren, maka alasan itu menjadi tidak relevan dalam konteks PP. AthThohariyyah. Pesantren ini melibatkan hampir seribu jumlah peserta didik dalam proses pembelajaran sehari-hari.

Nilai kompetitif lainnya adalah kemampuan PP. Ath-Thohariyyah menyerap semangat perubahan konteks sosial lingkungannya. Diakui bahwa umumnya pesantren tumbuh dan berkembang di tengah masyarakat agraris. Namun demikian, ini tidak berarti pesantren tidak dapat disentuh oleh pergeseran dan perubahan dari luar. Faktanya, pesantren tampak akomodatif terhadap tuntutan perubahan dan rasionalisasi. Antara lain; misalnya, perubahan budaya desa dari agraris menuju industrial telah menyebabkan terjadinya perubahan struktur kesadaran komunitas pesantren. ${ }^{34}$ Derasnya arus perubahan global telah membangun kesadaran dunia pesantren untuk konsisiten bersikap realistis dan rasional tanpa kehilangan jati dirinya. Dalam konteks inilah, adagium yang populer dalam tradisi pesantren; al-muhafadzat ala al-qadim ash-shalih wa al-akhdz bi aljadid al-ashlah dipahami dan diinternalisasi oleh para penglola pesantren, menjadi lebih dinamis, kreatif dan inovatif.

${ }^{34}$ Mahmud Arif. 2008. Pendidikan Islam Transformatif. Yogyakarta: LKiS, h, 187-188.

\section{PENUTUP}

Sesungguhnya pokok utama pendidikan pesantren dalam kajian dan pendalaman ilmu agama untuk mencetak dan mengkader calon ulama dapat dipadukan dengan pengembangan keterampilan dalam berbagai jenis dan pilihan sesuai dengan kemampuan dan kebutuhan wilayah lokal setempat, serta potensi sumberdaya setiap pesantren. Tugas dan peran pesantren sebagai lembaga pencetak ulama tidak berkurang bahkan justru bertambah nilai manfaatnya ketika pesantren mampu membekali para santrinya tidak hanya dengan pengetahuan tentang agama yang memang sudah menjadi tugas utamanya, melainkan juga keterampilan dan kecakapan yang bisa memberikan bekal kepada santri untuk mampu beradaptasi dalam menghadapi berbagai tuntutan dan tantangan dalam kehidupannya setelah menamatkan pendidikan di pesantren.

Upaya-upaya yang sedang dilakukan PP. Ath-Thohariyyah adalah bukti yang dapat menguatkan pernyataan tadi. Pesantren tersebut bahkan dapat menjadi model pesantren yang menginspirasi dan mendorong pesantren lain di wilayah Kabupaten Pandeglang, Banten dalam upaya memberikan bekal pendidikan yang seimbang antara kebutuhan mental spiritual keagamaan dan kebutuhan praksis kemasyarakatan. Santri tidak saja cerdas secara moral-intelektual, melainkan juga mampu memahami potensi dirinya sendiri dalam kehidupan, sehingga dapat menyusun tujuan-tujuan hidup dan melakukan proses pemecahan masalah apabila dihadapkan kepada persoalan-persoalan hidup kelak. Tegasnya, pendidikan keterampilan mengantarkan santri tumbuh menjadi seorang individu dan sekaligus bagian dari sebuah komunitas yang bisa bekerjasama dalam mencapai tujuan hidupnya.

Pesantren memang unik, berbeda dengan satuan pendidikan lain pada umumnya. Di pesantren ada jalinan sangat erat antara kiainyai, santri, keluarga santri, alumni dan masyarakat sekitar. Ini adalah modal sosial yang amat berharga. Potensi ini akan jauh berkembang lebih dahsyat manakala Pemerintah ikut andil memberikan dukungan sekaligus kontribusi riil dalam pengembangannya. Pesantren jelas telah berperan besar 
membantu sebagian tugas Pemerintah dalam penyelenggaraan pendidikan, termasuk menuntaskan Program Wajib Belajar Sembilan Tahun. Maka sangatlah wajar jika Pemerintah terlibat langsung dalam penyiapan dan pengembangan setiap komponen kependidikan pesantren. Maka PP. Ath-Thohariyyah membutuhkan dukungan Pemerintah dalam penyediaan sarana dan prasarana pendidikan serta penguatan SDM pendidik dan tenaga kependidikan. Sementara dalam pengembangan keterampilan, PP. AthThohariyyah membutuhkan pendampingan, pelatihan dan penguatan jaringan dalam rangka perluasan akses pemasaran produk pesantren. Namun demikian, tradisi dan otonomi pesantren tidak perlu diintervensi oleh pihak manapun, termasuk Pemerintah.

\section{DAFTAR PUSTAKA}

\section{Buku dan Undang-undang}

An-Nahidl, Nunu Ahmad. (2017). Pesantren Darul Fallakh: Gagahnya Santri Menjadi Petani dalam Murtadlo, dkk. Top 10 Ekosantri Pionir Kemandirian Pesantren. Jakarta, Litbangdiklat Press.

Arif, Mahmud. (2008). Pendidikan Islam Transformatif. Yogyakarta, LkiS.

Azra, Azyumardi. Pesantren: Kontinuitas dan Perubahan dalam Nurcholish Madjid. Bilik-bilik Pesantren. Jakarta, Penerbit Dian Rakyat.

Badan Litbang dan Diklat. (2017). Laporan Survei Pengajian Kitab Kuning di Pesantren Penyelenggara Pendidikan. Jakarta: Puslitbang Pendidikan Agama dan Keagamaan.

Bungin, Burhan. (2003). Analisis Data Penelitian Kualitatif. Jakarta: Raja Grafindo.

Bruinessen, Martin van. (1995). Kitab Kuning, Pesantren dan Tarekat. Bandung, Penerbit Mizan.

Dhofier, Zamakhsyari. (2015). Tradisi Pesantren: Studi Pandangan Hidup Kiai dan Visinya Mengenai Masa Depan Indonesia. Jakarta, LP3ES.
Dokumentasi Sekretariat PP. Pesantren AthThohariyyah Tahun 2017.

Harsono. (2008). Model-model Pengelolaan Perguruan Tinggi. Yogyakarta, Pustaka Pelajar.

Hasan, Muhammad Tholhah. (2005). Prospek Islam dalam Menghadapi Tantangan Zaman. Jakarta, Lantabora Press.

(2009). Mutu Pendidikan Islam sebagai Kunci Jawaban, Epilog dalam Asrori S Karni. Etos Studi Kaum Santri: Wajah Baru Pendidikan Islam. Bandung, Penerbit Mizan.

Hooker, Virginia. (2009). Pemahaman Baru Wajah Pendidikan Islam di Indonesia, Prolog dalam Asrori S Karni. Etos Studi Kaum Santri: Wajah Baru Pendidikan Islam. Bandung, Penerbit Mizan.

Mahfudh, Sahal. (1987). Pengembangan Masyarakat oleh Pesantren: Antara Fungsi dan Tantangan, dalam Pesantren, Nomor 2, Volume IV.

\section{Yogyakarta, LkiS.}

Moleong. (2007). Metodologi Penelitian Kuaitatif. Bandung, Remaja Rosdakarya.

Mughits, Abdul. (2008). Kritik Nalar Fiqh Pesantren. Jakarta, Kencana

Muhadjir, Noeng. (1992). Metodologi Penelitian Kualitatif. Yogyakarta, Penerbit Rake Sarasin.

Peraturan Pemerintah Nomor 19 Tahun 2005 tentang Standar Nasional Pendidikan.

Peraturan Pemerintah Nomor 55 Tahun 2007 tentang Pendidikan Agama dan Pendidikan Keagamaan.

Peraturan Menteri Agama Nomor 13 Tahun 2014 tentang Pendidikan Keagamaan Islam.

Qowa'id. (2007). KH Fuad Affandi: Spirit Pemikiran Salaf, Bentuk Pesantren Agrobisnis, dalam Pemikir Pendidikan Islam: Biografi Sosial Intelektual. Ed. Choirul Fuad Yusuf. Jakarta, Pena Citasatria. 
Sugiono. (2008). Metode Penelitian Pendidikan. Bandung, Alfabeta.

Suprayogo, Imam. (2012). Spirit Islam Menuju Perubahan dan Kemajuan. Malang: UIN Maliki Press.

Usmani, Ahmad Rofi. (2016). Jejak-jejak Islam. Yogyakarta, Penerbit Bunyan.

UU Sistem Pendidikan Nasional Nomor 20 Tahun 2003.

Undang-undang Nomor 20 Tahun 2003 tentang Sistem Pendidikan Nasional.

Wahid, Abdurrahman. (1974). Pesantren sebagai Subkultur, dalam M. Dawam Raharjo (Ed). Pesantren dan Pembaruan. Jakarta, LP3ES.

Yunus, Firdaus M. (2005). Pendidikan Berbasis Realitas Sosial - Paulo Freire YB Mangunwijaya. Yogyakarta, Logung Pustaka.

\section{Website}

Pengangguran di Indonesia Tinggi Karena Lulusan Perguruan Tinggi Terlalu 'Milih' Pekerjaan. http://m.tribunnews.com/ nasional/2017/11/08/pengangguran-diindonesia-tinggi-karena-lulusanperguruan-tinggi-terlalu-milihpekerjaan?page $=3$. Diakses 3 September 2018.
Jumlah Pengangguran Terdidik, Ya Ampun ! Lihat: https://m.jpnn.com/news/jumlahpengangguran-terdidik-ya-ampun. Diakses 3 September 2018.

\section{Wawancara}

Wawancara dengan Umi Eha, Pengasuh PP. Pesantren Ath-Thohariyyah, pada Kamis, 24 Mei 2017 dan Selasa, 1 Agustus 2017.

Wawancara dengan Ustad Bahruddin, Pengasuh PP. Ath-Thohariyyah, pada Selasa, 1 Agustus 2017.

Wawancara dengan Drs. KH. Moh. Suhri Utsman, tokoh masyarakat, Pengurus MUI dan Baznas Propinsi Banten, pada Rabu, 2 Agustus 2017.

Wawancara dengan Elif Lathifah, Bendahara PP. Ath-Thohariyyah, pada Rabu, 24 Mei 2017 dan Selasa, 1 Agustus 2017. 